\title{
PEMBENTUKAN KARAKTER IDIOLOGI MODERAT DI PESANTREN NGALAH PURWOSARI PASURUAN
}

\author{
Nafilatul Fitriyah, Muhammada \\ muhammada@yudharta.ac.id \\ Universitas Yudharta Pasuruan
}

\begin{abstract}
Every human being must have different characters. From these different characters can also make a difference that can lead to division. However, if the character differences can be harmonized with the formation of characters that are continuous and are continuous. Because of the formation of characters that are only half-done, it will make someone not only misunderstood but understand wrong. Based on the results of the data obtained stating the character of the santri can be formed with several attitudes to make it towards moderate character. As with applying the attitude of love of God, and all its creation, honesty / trust, respect and courtesy, tolerance, please help and mutual cooperation / cooperation, fairness, the spirit of nationalism, love of peace. The attitude is applied in the daily activities of the santri, the weekly activities of the santri, the monthly activities of the santri, the annual activities of the santri and activities that are incidental.
\end{abstract}

Keywords: Character, Ideology, Moderate.

\section{PENDAHULUAN}

Karakter Islam moderat adalah ajaran Islam rahmatan lil'alamin yang sangat cocok dengan alam demokrasi ala Indonesia yang lazim disebut dengan Islam nusantara, sehingga Islam memiliki kontribusi yang signifikan bagi pemersatu bangsa dalam menjaga keutuhan NKRI, oleh karena itu Islam moderat di Indonesia merupakan suatu keniscayaan, dan karenanya harus dipromosikan kepada segenap anak bangsa di seluruh pelosok bumi nusantara. ${ }^{1}$

Islam moderat ini sejatinya sudah disuarakan oleh founding father's NKRI sejak awal (era orde lama dan orde baru), pada era reformasi tidak kurang mantan presiden SBY (kala itu masih presiden) menyatakan bahwa

\footnotetext{
${ }^{1}$ M. Sidi Ritaudin, Promosi Islam Moderat Menurut Ketum (Mui) Lampung Dan Rektor Universitas Islam Negeri (Uin) Raden Intan Lampung. Jurnal TAPIs Vo. 13 No.02 JuliDesember 2017, h.1.
} 
Indonesia akan menjadi model Islam moderat yang berkomitmen menekan radikalisme dengan cara yang tidak melanggar HAM dan menjunjung demokrasi. Ia juga menyatakan bahwa tidak perlu ada konflik antara Islam dengan modernitas dan demokrasi. ${ }^{2}$

Pondok Pesantren Ngalah merupakan salah satu dari lembaga pendidikan yang mewakili untuk menciptakan perdamian dunia. Dengan bimbingan dan asuhan romo Kyai Sholeh Bahrudin dengan prinsipnya yang sangat mulia yaitu ngayomi lan ngayemi terhadap sesama makhluk. Berangkat dari prinsip beliau menjadikan Pondok Pesantren Ngalah menjadi pesantren satu-satuya di daerah Pasuruan yang menerapkan ideologi moderat. Dimana makna ngayomi adalah melindungi atau memproteksi sesama manusia, sedangkan ngayemi bermakna menjadikan orang lain aman dari gangguan. ${ }^{3}$

Ideologi moderat merupakan hal yang penting bagi Pondok Pesantren Ngalah dalam mewujudkan visi dan misi Pesantren Ngalah. Visi dari Pondok Pesantren Ngalah "Membentuk Santri yang Rahmatan Li al-Alamin", tidak hanya pada visi saja yang dapat menciptakan karakter moderat pada santri Ngalah akan tetapi di imbangi dengan misi yang sangat bagus yaitu: ${ }^{4}$ a) Menanamkan aqidah dan mengamalkan syariat Islam yang berhaluan Ahl alSunnah wa al-Jama'ah. b) Memberdayakan potensi santri dalam wawasan keagamaan, keilmuan, keorganisasian, kemasyarakatan dan kebangsaan sesuai kultur pesantren. c) Mengimplementasikan nilai-nilai moral dalam dinamika kehidupan kemasyarakatan. d) Menyiapkan santri yang unggul dalam IMTAQ dan IPTEK.

Pondok pesantren yang dengan beckground ke NU-an juga tidak luput dari prinsip Nahdhatul Ulama dengan menerapkan sikap tawassuth (moderat), I'tidal (tegak), tasamuh (toleran), dan tawazun (seimbang). Dengan begitu Pondok Pesantren Ngalah menyikapi segala perbedaan yang ada dengan sikap tenang dan dengan sikap besar hati karena dengan adanya perbedaan itu menjadikan warna dan lebih untuk tetap berfikir positif dan selalu bersyukur akan keberbedaan sebagai rahmat dari Allah.

Pondok Pesantren Ngalah dalam mengimplementasikan sikap Islam moderat dengan menerima semua tamu meskipun dari golongan khusu' sampai dengan golongan blusuk. KH. Sholeh Bahruddin merupakan

\footnotetext{
${ }^{2}$ Ibid, 2017, h. 2.

${ }^{3}$ M. Muntahibun Nafis. Pesantren Pluralis, (Yogyakarta: Insani madani, 2017), h. Xiv.

${ }^{4}$ Ibid, 2017, h. 134.
} 
pengasuh Pondok Pesantren Ngalah sekaligus mursyid tarikat serta sebagai salah satu tokoh moderat, terbukti dengan sikap, perilaku, dan pemikirannya yang mampu menuangkan ajaran dan nilai-nilai agama secara terbuka dan dialogis baik kepada santri, mahasiswa, dan berbagai elemen masyarakat yang mulitikultural. ${ }^{5}$

Tidak hanya itu juga yang romo kyai ajarkan pada santri-santriwatinya. menyikapi tahun politik romo kyai sangat gencar memberikan petuah-petuah bijaknya dalam membimbing dan mengarahkan semua santrinya agar tidak sampai terjerumus dalam lubang kegelapan politik. seperti yang romo kyai dawuhkan di pengajian tafsir tanggal 24 Desember 2018 bahwasannya yayasan Darut Taqwa dan lembaganya cara menyikapi tahun politik dipersilahkan kepada semua dosen, guru, ustadz, pegawai, santri, siswa, mahasiswa, alumni, jamaah, memilih partai manapun dan capres cawapres manapun dengan aman dan damai. Jangan sampai ikut haluan ekstrim kanan atau ekstrim kiri, jadilah ummatan wasathon/moderat yaitu luwas luwes, ramah, mohon dibaca Jawabul Masail, semoga bermanfaat semuanya. ${ }^{6}$

Strategi yang dilakukan oleh romo kyai dalam menanamkan ideologi moderat kepada para santrinya tidak hanya dilakukan dengan memeberikan pencerahan lewat dawuh yang dilakukan pada saat pengajian tafsir berlangsung akan tetapi salah satunya dengan mengumpulkan semua santri madrasah diniyah mulai jenjang wusthiyah sampai jenjang mualimin mualimat tidak lupa para ustadz dan ustadzahnya untuk dibekali wawasan tentang Islam moderat. Dengan harapan fungsi dari pesantren sendiri dapat dipahami oleh seluruh santrinya yang mana fungsi dari pesantren sendiri adalah "Ajining diri soko lathi" artinya kehormatan seseorang berada pada apa yang diucapkan dan disampaikannya, dengan begitu supaya mereka jika bertindak dan berbicara selalu sopan santun dan lembut. Sebab kalimat yang indah adalah pertanda hati yang bersih.

Dalam moment tersebut romo kyai memberikan contoh nyata sebuah buku yang berwawasan antara dari pihak ekstrem kanan dan pihak ekstrem kiri. Dalam hal ini romo kyai menunjukkan bahwasannya Pondok Pesantren Ngalah menjadi penengah dari kedua belah pihak tersebut dengan adanya buku jawabaul masail dimana buku tersebut memberikan jawaban dari

\footnotetext{
${ }^{5}$ Ibid, M. Muntahabudin Nafis, 2017, h. 134.

${ }^{6}$ Dawuh romo kyai pengajian tafsir. Masjid Asrama A. 24 Desember 2018, Jam 16.30 WIB
} 
permasalahan yang menjadikan pandangan Islam menjadi agama yang keras dan agama radikal.

Sikap moderasi yang seperti ini mutlak dilakukan sebagaimana dilihat bahwasannya Islam sebagai kelompok mayoritas di republik ini dapat menjadi teladan dalam membangun toleransi dalam konteks kebangsaan. ${ }^{7}$ Karena dengan kita bersikap moderat yang secara otomatis menimbulkan sikap toleransi maka terciptalah hidup di dunia ini penuh kedamaian dan saling menyayangi antar sesama.

Menurut Abudin Nata pendidikan moderat memiliki sepuluh nilai dasar yang menjadi indikatornya, yaitu: 1) pendidikan damai, yang menghormati hak asasi manusia dan persahabatan antara bangsa, ras, atau kelompok agama. 2) pendidikan yang mengembangkan kewirausahaan dan kemitraan dengan dunia industri. 3) pendidikan yang memperhatikan visi misi profetik Islam, yaitu humanisasi, liberasi dan transenderasi untuk perubahan sosial. 4) pendidikan yang memuat ajaran toleransi beragama dan pluralisme. 5) pendidikan yang mengajarkan paham Islam yang menjadi mainstream Islam Indonesia yang moderat. 6) pendidikan yang menyeimbangkan antara wawasan intelektual (head), wawasan spiritual dan akhlaq mulia (heart) dan keterampilan vokasional dan intelek yang ulama 8) pendidikan yang menjadi solusi bagi problem-problem pendidikan saat ini seperti masalah dualism dan metodologi pembelajaran. 9) pendidikan yang menekankan mutu pendidikan secara komprehensif dan 10) pendidikan yang mampu meningkatkan penguasaan atas bahasa asing. ${ }^{8}$

\section{PEMBENTUKAN KARAKTER DALAM IDEOLOGI MODERAT}

Dari hasil penelitian bahwa pembentukan karakter moderat di Pondok Pesantren Ngalah merupakan keinginan dari romo kyai dalam membimbing para santrinya agar dalam hidup di masayarakat dapat bersikap luwas dan luwes. Pada pembentukan karakter tersebut dilihat dari kegiatan sehari-hari, mingguan, bulanan, dan tahunan. Dari kegitan santri tersebut dapat membentuk sikap cinta Tuhan dan segenap ciptaam-Nya, kejujuran/amanah dan kearifan, hormat dan santun, suka menolong dan gotong royong/kerja sama, toleransi, semangat nasionalisme dan kebangsaan, cinta tanah air, cinta

\footnotetext{
${ }^{7}$ Zuhairi Misrawi, Muslim Moderat Toleransi, Terorisme, dan Oase Perdamaian, (Jakarta: Kompas Media Nusantara, 2010), h. xiii

${ }^{8}$ Toto Suharto, Indonesianisasi Islam: Penguatan Islam Moderat dalam Lembaga Pendidikan Islam di Indonesia, Al-Tahrir: Jurnal Pemikiran Islam, 17(1), 2017, h. 168.
} 
damai. Sikap tersebut dilatih dalam kebiasaan santri untuk mencapai kompetensi yang sesuai dibarengi dengan keinginan yang kuat.

Berikut ini beberapa sikap yang diterapkan oleh para santri dalam membentuk moderat di Pondok Pesantren Ngalah.

1. Sikap cinta Tuhan dan ciptaan-Nya

Dari sikap ini para santri di ajarkan bagaimana menumbuhkan sikap cinta kepada Tuhannya dan ciptaan-Nya dengan para santri diberinasihat oleh para pengasuhnya setiap asramanya di setiap awal kembali pondok bahwasannya niatnya di tata kembali. Bahwasannya niat mondok untuk menghilangkan kebodohan dan kenakalan. Tidak hanya itu para santri juga didoktrin bahwasannya segala sesuatu yang dilakukan harus karena Allah atau lillahitaallah. ${ }^{9}$

Untuk penerapan sikap cinta kepada segenap ciptaan-Nya adalah para santri juga di beri amanat untuk tetap bersikap baik kepada santri yang baru, diibaratkan sebagai investasi atau membayar hutang selama menjadi santri yang sudah krasan di pondok. ${ }^{10}$ Para santri juga diharuskan untuk berbuat baik kepada semua orang tanpa memandang dari segi apapun dan dari golongan apapun.

2. Kejujuran/amanah

Sikap kejujuran dilakukan para santri ketika membeli makanan di kantin asramanya masing-masing. Pada saat membeli makanan di kantin para santri tinggal ambil sendiri makanan apa yang diinginkan dan membayarnya dengan tinggal menyebutkan nominal habis berapa makanan yang dibelinya.

Tidak hanya dalam kegiatan para santri makan di kantin akan tetapi jika para santri di amanati oleh wali santri dari salah seorang temannya maka bagi santri yang mendapatkan amanat tersebut wajib menyampaikan pesan tersebut.

Para santri juga dibiasakan untuk mengakui kesalahan yang dibuat dengan wujud berupa menjalankan takziran yang telah ditentukan. Seperti halnya mengakui kesalahannya jika tidak ikut sholat berjamaah dan melanggar jam mandi.

\footnotetext{
${ }^{9}$ Dawuh Romo kyai pada saat para pengurus sowan setelah liburan Idul fitri. Di ndalem romo Kyai. Pukul 06.00 WIB

${ }^{10}$ Dawuh romo kyai pada pengajian tafsir pada tanggal 30 Juni di masjid asrama A. Pukul 16.45 WIB
} 
3. Hormat dan santun

Sikap hormat dan santun ini sangat perlu di miliki bagi setiap para santri. Karena seorang santri identik dengan sikap kehormatannya dan kesantunannya kepada semua orang.

Pada hal ini para santri di biasakan dengan jika berteu dengan romo kyai ataupun bu yai serta para gawagus dan gawaneng maka sikap santri di haruskan untuk berhenti sejenak dari perjalannya dan menundukkan kepala. Tidak hanya itu para santri di biasakan jika bertemu kedua orang tua dan seorang yang lebih tua darinya maka diharuskan mengucapkan salam dan mencium tanggan dengan kedua tangannya.

Dan bagi para pengurusnya memberikan sikap uswatun khasanah kepada para adik-adiknya dengan tetap memakai bahasa krama inggil, agar suapaya para santri terbiasa memakai bahasa krama kepada kedua orang tuanya dan kepada orang yang lebih tua darinya.

4. Sikap menolong dan gotong royong/kerjasama

Dalam membina sikap ini di pondok pesantren sangatlah kental dengan adanya kegiatan roan. Dimana kegiatan tersebut dilakukan kadang di pagi hari, siang hari maupun sore hari. Dalam kegiatan tersebut tetap di dampingi oleh pengasuhnya dengan harapan membntuk sikap saling tolong menolong dan kerjasama dalam menyelesaikan suatu pekerjaan dikecualilkan pada saat mengerjakan soal ujian.

Tidak untuk pada kegiatan roan saja membentuk sikap menolong dan gotong royong akan tetapi juga di terapkan pada saat belajar bersama atau sawir di asrama, kerjasama dalam memberikan pemahan dan pengentahuan bagi santri yang belum paham akan suatu masalah atau suatu pelajaran.

5. Toleransi

Sikap toleransi sangat menonjol pada Pondok Pesantren Ngalah. Karena pondok pesantren salah satu pondok pesantren yang menerapkan sikap toleransi dan membuka bagi semua kalangan untuk belajar bersama di Pondok Pesantren Ngalah. Sikap toleransi yang biasa para santri lakukan yaitu menerima tamu dan menyediakan tempat tinggal bagi tamu dari kalangan beda agama.

Menerima berbagai budaya dari semua kalangan yang tidak menyimpang dari ajaran. Seperti halnya turut mengundang kesenian barongsai dari setiap even-even pondok pesantren. 
Mengahdiri undangan ke gereja sebagai rasa menghargai dan memnyambung tali persaudaraan antara sesama manusia meskipun berbeda agama. Semua sikap dilakukan bukan lain karena didikan dari romo kyai yang selalu membuka pintu rumahnya bagi semua kalangan tanpa membeda-bedakan dan berbuat baik kepada semuanya.

Tidak hanya dalam segi sosial saja pondok ngalah melakukan sikap toleransi akan tetapi ditunjukkan dalam segi memberikan hukum terhadap agama dengan di terbitkannya buku karanagan santri pondok nagalah berupa buku Jawabul Masail dimana didalamnya memberikan keluwesan dalam mengambil hukum untuk diterapkan dalam kehidupan sehari-hari. Sehingga tidak mudah mengatakan haram pada seseuatu hal yang jarang dilakukan oleh kebanyakan orang.

6. Semangat nasionalisme dan kebangsaan

Bagi para santri di berikan nasihat untuk menjadi santri yang berakhlakul karimah serta tidak lupa dengan semangat nasionalismenya. Dibuktikan dari setiap hari santri, para santri ngalah putra putri diwajibkan mengikuti apel untuk memperingati hari santri yang dilakukan di lapangan Universitas Yudahrta.

Tidak hanya itu saja pada saat bulan Agustus dari setiap asrama mengadakan lomba tujuh belasan untuk memperingati hari kemerdekaan dengan harapan menanamkan rasa nasionalisme pada santri. Kemudian dari kegiatan muhadharoh santri para santri di haruskan untuk membuat tema kemerdekaan dengan versi kamarnya masing-masing.

7. Adil

Sikap adil adalah sikap dimana kita mengerjakan sesuai dengan kebutuhan kita. Dari sikap adil ini para santri dapat menerapkan dari melakukan kegiatan sesuai dengan hak dan kewajibannya masing-masing.

Seperti halnya adil dalam menata waktunya, misalnya waktu pagi waktunya sekolah formal jika ada salah satu santri tidak masuk sekolah tanpa adanya halangan apapun maka wajib menerima takziran berupa menguras kolam asrama, waktu jamaah tidak jamaah maka diberikan takziran berupa membaca al-Quran sebanyak 5 lembar.

8. Cinta damai

Sikap cinta damai yang dilakukan para santri Pondok Pesantren Ngalah dengan adanya dawuh romo kyai bahwasannya semua santri baik alumni santri ngalah dilarang keras untuk mengikuti demo. 
Dan romo kyai beserta keluargamya dalam menyikapi bulan politik beliau-beliau menerapkan sikap netra dan terhadap kedua belah kubu. Romo kyai dan keluarga hanya bisa membantu doa agar apa yang diperoleh dari hasil akhir memberikan manfaat bagi bangsa dan negara.

9. Implementasi dalam Ideologi Moderat pada Pondok Pesantren Ngalah

Dari hasil wawancara yang tidak terstruktur dan hasil observasi serta dokumentasi bahwa pelaksanaan ideologi moderat pada Pondok Pesantren Ngalah yang sudah ada dan menjadi ciri khas dari Pondok Pesantren Ngalah tersebut yang dilakukan dalam setiap kegiatan santri di Pondok Pesantren Ngalah yang lebih jelasnya akan dijabarkan sebagai berikut:

Kegiatan Sehari-Hari

a. Sholat subuh berjamah

b. Sorogan

c. Mengaji 3 surat (surat yasin, surat waqiah, surat ar-Rahman)

d. Sholat dhuha berjamaah

e. Sekolah

f. Sholat dhuhur berjamaah

g. Sholat ashar berjamaah

h. Pengajian tafsir

i. Sholat magrib berjamaah

j. Madrasatul Qur'an (MQ)

k. Sholat isya' berjamaah

1. Madrasah diniyah

m. Pengajian surat al-Mulk

\section{KONSEP PEMBENTUKAN KARAKTER DALAM IDEOLOGI MODERAT DI PONDOK PESANTREN NGALAH}

Dari data yang telah dideskripsikan dapat diketahui bahwasannya pembentukan karakter moderat yang dilakukan di Pondok Pesantren Ngalah adalah dengan melalui penerapan sikap cinta Tuhan dan segenap ciptaanNya, kejujuran/amanah dan kearifan, hormat dan santun, suka menolong dan gotong royong, toleransi, semangat nasionalisme dan kebangsaan, cinta tanah air, cinta damai.

1. Cinta Tuhan Dan Segenap Ciptaan-Nya

Dalam sikap yang diterapkan oleh para santri Ngalah untuk menumbuhkan sikap cinta Tuhan dan segenap Ciptaan-Nya diterapkan 
dalam kegiatan sehari seperti melaksanakan perintah-perintah Tuhan dan menjauhi larangan-larangannya dan biasa dikatakan dengan Islam tempat penyucian anggota-anggota dari dosa dan menghiasi dengan tujuan taat kepada Tuhan. ${ }^{11}$

Para santri dilatih untuk melaksanakan sholat wajib dengan berjamaah agar dalam melaksanakan sholat itu tidak merasa berat. Kemudian selain melaksanakan sholat fardhu para santri juga diajarkan untuk melakukan sholat sunnah seperti halnya sholat taubat, sholat dafil bala', sholat birul walidain, sholat dhuha dan sholat hajat.

Tidak hanya itu para santri dilarang keras berdekatan dengan hal yang berbau narkoba atau sabu, sesuai dengan dawuh romo kyai bahwasannya bagi santri yang melakukan pelanggaran itu berarti daftar bodoh. Peraturan yang lebih mendalam lagi para santri dilarang keras untuk berbuat zina, jika sampai terjadi maka romo kyai tidak akan mengakui sebagai santrinya.

Untuk penerapan cinta kepada segenap ciptaan-Nya adalah utuk selalu berbuat baik kepada semuanya, dan para santri dilarang keras tukaran terhadap sesama temannya. Jika melakukan tukaran dengan temannya maka sama halnya mengadu domba antara kedua orang tua dengan romo kyai. Romo kyai pernah dawuh kepada para santri jika mau tukaran dengan temannya ada niatnya yaitu niat ngadu domba bapak ibuk dengan romo kyai.

2. Kejujuran/Amanah

Kejujuran yang dilakukan para santri Ngalah adalah dengan menanamkan prinsip mondok di Ngalah dengan tirakat menaati peraturan. Karena letak pondok pesantren putri dan pondok pesantren putra sangatlah dekat hampir tidak ada sekat sama sekali. Jadi hanyalah kejujuran lah yang dapat membentengi untuk tidak melakukan kegiatan yang dilarang oleh pondok pesantren. Seperti halnya ketemuan antara santri putra an santri putri tanpa adanya kepentingan yang mendesak.

Dari penerapan sikap amanah oleh para santri adalah dpat menjalankan apa yang telah di jadikan aturan di pondok pesantren dengan mengemban amanat dari kedua orang tuanya. Dan sikap amanah ini lebih harus di tekankan pada para pengurus asrama yang diberikan amanah

\footnotetext{
${ }^{11}$ Santri mbah KH. Munawir Kertosono dan santri Mbah KH. Sholeh Bahrudin, Sabilus salikin jalan para salik ensiklopedia thariqah/tasawwuf, (Sengonagung: Pondok Pesantren Ngalah, 2012), h. 122.
} 
untuk membantu romo kyai dalam mebimbing adik-adik santri sehingga merasa nyaman di pondok dan mau belajar di pondok.

3. Hormat Dan Santun

Sikap hormat dan santu itu hal yang prlu diperhatikan pada akhlaq santri. Seperti halnya jika bertemu dengan romo Kyai dan bu nyai serta keluarga ndalem, para santri secara otomatis langsung berdiam diri dan memberhentikan pembicaraan serta menundukkan kepala sampai romo kyai dan bu nyai beserta keluarga ndalem lewat.

Para santri dibiasakan dengan selalu memakai bahasa krama inggil kepada pengurus dan teman kamar yang lebih tua umurnya diharapakan agar melatih berbahasa kram inggil kepada kedua orang tuanya. Tidak hanya itu pula para santri kerap diingatkan ketika pengajian tafsir romo kyai untuk bersalaman dengan tangan dua ketika bertemu dengan orang tua dan gurunya.

Kebiasaan sebelum pulangan pondok romo kyai selslu mengingatkan kepada para santri untuk tidak bermain hp terus menerus dan tidur yang terlalu lama. Romo kyai selalau mengingatkan untuk membantu kesusahan kedua orang tuanya.

Kemudian jika musim santri baru, para santri dilarang berdiam diri jika di tanyai oleh wali santri yang tidak mengerti tempat pendaftaran, maka wajib bagi santri tersebut mengantar wali santri tersebut ke tempat pendaftaran.

4. Sikap Menolong Dan Gotong Royong

Sikap gotong royong yang dilakukan oleh santri Ngalah ditunjukkan dengan melakukan roan dlam pembanguan semua gedung yang ada di Pondok Pesantren Ngalah. Seperti halnya pembangunan gedung asrama $\mathrm{J}$ dan $\mathrm{K}$ kemudian pembangunan gedung koperasi serta yang baru ini pembangunan gedung asrama $\mathrm{N}$ dan $\mathrm{O}$. Akan tetapi dalam melaksanakan roan tersebut tetap didampingi oleh para bapak-bapak tukang yang sudang handal.

Tidak hanya itu jika ada kerusakan atau masalah di asrama putri maka pengurus santri putri meminta bantuan kepada tetangga asrama putra.Dan jika dari tetangga asrama yang kehabisan air maka dengan rasa tolong menolong asrama yang persediaan airnya cukup memberi tumpangan mandi dan wudhu' bagi asrama yang kehabisan air. 
5. Toleransi

Sikap toleransi yang dilakukan para santri ngalah adalah dengan menerima tamu dari kalangan beda agama. Kemudian mempersilahkan bagi umat agama lain untuk melakukan studi banding di Pondok Pesantren Ngalah.

Kemudian menerima kesenian budaya dari beda agama. Yang biasanya ditampilkan pada event-event pondok pesantren. Seperti halnya pada ulang tahun Pondok Pesantren Ngalah yang di rayakan oleh saudara dari beda agama. Kemudian pada ulang tahun kampus Yudharta selalu menampilkan budaya-budaya tradisional dan modern yang tidak menyimpang dari ajaran agama Islam.

Kemudian pada haflah ke-30 kemarin sengaja panggung di dekorasi seperti halnya sebuah klenteng dan dari acara pra haflah juga menampilkan kesenian modern seperti halnya menampilkan orkestra Pondok Pesantren Ngalah serta menampilkan ludruk kolosal para santri ngalah.

Tidak hanya itu toleransi para santri ngalah ditunjukkan denga karangan buku jawabul masail. Di dalam buku tersebut menjelaskan tentang toleransi antar umat beragama. Karena perbedaan itu membrikan rahmat bagi kita semua yang mau berfikir akan perbedaan tersebut. ${ }^{12}$

6. Semangat Nasionalisme Dan Kebangsaan

Semangat nasionalisme yang ditunjukan oleh santri ngalah dengan di adakan acara pengibaran bendera serta penurunan bendera merah putih pada saat hari kemerdekaan bangsa Indonesia.

Tidak hanya itu bagi setiap asrama mengadakan lomba kebangsaan seperti lomba karikatur tokoh pahlawan, pembacaan teks proklamasi, kemudian lomba merias sesuai dengan tokoh pahlwan yang diminati.

Kemudian pada hari santri para santri dan pegawai yayasan ikut serta dalam upacara dalam memperingati hari santri yang dialkukan di lapangan kanpus Yudharta dan dipimpin langsung oleh gus Saikhu.

Untuk kegiatan rutinan para santri yaitu muhadarah yang diharuskan memakai tema kemerdekaan dengan kreasi dan sekreatif mungkin dari kelompok yang bertugas.

\footnotetext{
${ }^{12}$ Santri Pondok Pesantren Ngalah, Ensiklopedi Fiqih Jawabul Masail Bermadzhab Empat, (Sengonagung:Pondok Pesantren Ngalah, 2013), h. 24.
} 
7. Adil

Sikap adil yang dimaksudkan dan diterapkan oleh Pondok Pesantren Ngalah adalah adil dalam memanfaatkan waktu yang ada. Karena dilihat dalam kegiatan mulai pagi sampai malam ada banyak waktu yang dapat digunakan untuk hal yang lebih bermanfaat seperti halnya dengan membuat waktu luang tersebut menjadi waktu yang tepat untuk mengahafalkan al-Quran, serta menghafal nadzom-nadzom sesuai dengantingkat kelas diniyahnya.

Jika waktunya sekolah formal di pergunakan untuk mempelajari dan mendalami ilmu yang bersufat keduniawian. Sedangkan pada saat sekolah diniyah para santri bisa memanfaatkan waktunya untuk mempelajari ilmu yang berkaitan dengan ilmu keagamaan. Jika pada saat madrasatul qur'an digunakan untuk mempelajari teori dalam membaca alQuran.

8. Cinta Damai

Sikap cinta damai yang dilakukan Pondok Pesantren Ngalah atas dasar araha dari romo kyai. Seperti halnya para santri dilarang keras untuk mengikuti demo pada saat pilpres 2019 kemarin. Tidak hanya itu juga para santri diharuskan menhgormati dan menghargai masyarakat non muslim agar tercipta kedamaian.

Seperti halnya maklumat pengasuh tentang "Mengapa Pondok Pesantren Ngalah Dekat Dengan Non Muslim,"13

a. Agar pondok pesantren ala NU terbukti bukan sarang teroris karena teroris tidak berperilaku kemanusiaan.

b. Supaya masyarakat musli dan non muslim bisa hidup rukun, damai, dan saling berdampingan.

c. Biar para santri biasa berwawasan kebangsaan, tanpa membedabedakan dan berjiwa Rahmatal lil 'alamin serta berperilaku Ukhuwah Basyariyah.

\section{IMPLEMENTASI PEMBENTUKAN KARAKTER DALAM IDEOLOGI MODERAT DI PONDOK PESANTREN NGALAH}

Dari data yang telah di diskripsikan dapat di ketahui bahwasannya penerapan ideologi moderat di Pondok Pesantren Ngalah sudah dilakukan sejak lama dan menjadi ciri khas dari Pondok Pesantren Ngalah.

${ }^{13}$ Ibid, h. 32.

Nurnal al-Murabli, Volume 4 Namar 2, Jumi 2019 
Pengimplementasian dari sikap moderat Pondok Pesantren Ngalah dilakukan dalam rutinitas santri Pondok Pesantren Ngalah seperti halnya pada kegiatan sehari-hari santri,kegiatan mingguan santri dan kegiatan yang bersifat bulanan serta kegiatan yang bersifat insidental.

1. Kegiatan Harian Santri

Pada kegiatan sehari-hari santri dapat membentuk karakter moderat dengan cara melaksanakan sholat 5 waktu dan melaksanakan sholatsholat sunnah seperti halnya: sholat dhuha, sholat taubat, sholat daf'il balak, sholat birul walidain, sholat hajat. Dengan melaksanakan kegiatan tersebut santri bisa menerapkan sikap rasa cintanya terhadap tuhan.

Setiap sore harinya santri melakukan kegiatan pengajian tafsir yang langsung dipimpin oleh Romo Kyai Sholeh Bahruddin dan dalam pengajian tersebut para santri diberi nasihat-nasihat untuk mempertebal iman kepada Tuhan. Setelah pengajian tafsir dilanjutkan dengan pengajian kitab Ta'lim Muta'allim yang dipimpin oleh pak Syaifullah dimana dalam kitab tersebut para santri diajarkan bagaimana bersikap menghargai dan menyayangi ciptaan Tuhan serta sopan santun terhadap sesama manusia.

Tidak hanya kegiatan itu saja untuk menciptakan sikap rasa cintanya kepada tuhan, biasanya santri melakukan pembacaan surat yasin, al-Waqi'ah, ar-Rahman, al-Mulk yang dilakukan setiap pagi harinya kecuali surat al-Mulk yang dibaca sepulang sekolah non formal (diniyah).

Dan setiap harinya santri melakukan kegiatan MQ di asrama masing-masing yang dilakukan setelah sholat maghrib. Setelah jama'ah sholat isya' semua santri bergegas berangkat madrasah diniyah.

2. Kegiatan Mingguan Santri

Dari hasil penelitian kegiatan mingguan santri dapat membentuk karakter moderat pada santri dengan adanya kegiatan berupa Muthola'ah yang mana dapat menumbuhkan sikap tolong-menolong dalam hal keilmuan. Tidak hanya pada Muthola'ah saja akan tetapi pada tingkatan mahasiswa diadakannya kegiatan debat mahasiswa yang mana bertujuan melatih meanset mahasiswa dalam menanggapi problematika di era globalisasi.

Bukan hanya itu saja yang dilakukan para santri untuk membentuk karakter moderat di Pondok Pesantren Ngalah ini misalnya: kegiatan pembacaan diba'iyah dan manaqib yang mana kegiatan ini dilakukan oleh setiap kamar secara bergilir dan kegiatan ini dapat menumbuhkan rasa 
kerjasama yang baik untuk mendapatkan hasil yang maksimal dan menumbuhkan sikap adil dari pembagian pembacaan diba'iyah dan manaqib.

Dan pada waktu libur sekolah setiap minggunya para santri melakukan kegiatan muhadhoroh yang dilakasanakan pada hari jum'at, kegiatan tersebut dapat menumbuhkan rasa cinta damai dan toleransi. Kegiatan skill pemahaman kitab dan jawabul masail dapat menumbuhkan sikap toleransi, semangat nasionalisme dan kebangsaan dan cinta terhadap Tuhan dan ciptaan-Nya.

3. Kegiatan Bulanan Santri

Kegiatan bulanan santri di Pondok Pesantren Ngalah biasanya melaksanakan Dzikrul Ghofilin dan Istighosah di asrama masing-masing yang dapat menumbuhkan rasa cinta terhadap Tuhan dan kejujuran serta amanah.

Selain kegiatan itu dilakukan acara muhadhoroh kubro yang diikuti oleh semua asrama putri dan dimana pada setiap asrama di wajibkan untuk menampilkan hasil undian yang sudah disepakati oleh semua asrama putri dari kegiatan tersebut dapat membentuk sikap sopan santun, adil, dan toleransi serta sikap tolong-menolong/kerjasama untuk mensukseskan acara tersebut.

4. Kegiatan Tahunan Santri

Kegiatan tahunan diPondok Pesantren Ngalah meliputi: sya'banan, muharroman, santunan kepada anak yatim (sunnat massal), lalaran akbar nadzom imriti dan alfiah ibnu malik yang bertempat dimasjid aminah Pondok Pesantren Ngalah dan haflah akhirussannah serta peringatan PHBI (Peringatan Hari Besar Islam), melaksanakan sholat malam lailatul qodr bersama di halaman masjid aminah Pondok Pesantren Ngalah.

Dari kegiatan tersebut dapat membentuk sikap cinta Tuhan dan segenap ciptaan-Nya, tolong-menolong/kerjasama, cinta damai, semngat nasionalisme dan kebangsaan.

5. Kegiatan Insidental

Dari hasil penelitian yang telah diskripsikan ada beberapa kegiatan bersifat insidental yang mencerminkan sikap moderat santri Pondok Pesantren Ngalah adalah pertama pada tanggal 18 Mei 2019 para santri Pondok Pesantren Ngalah mahasiswa yudharta menghadiri undangan pembagian takjil sekaligus buka bersama di Gereja GKJW Pandaan dalam rangka menjalin kerukunan antar umat beragama. Kedua pada 21 
April 2019 pada acara siswa-siswi kelas XII SMK Darut Taqwa dengan menampilkan Swallow Band, Teater Mata Angin, serta mengundang Geranium Band sebagai Guest Star. Ketiga pada 25 Desember 2018 ucapan selamat natal dari santri pondok pesantren nglah untuk umat kristen dengan tujuan kerukunan dan perdamaian NKRI. Keempat pada 13 September 2018 dalam rangka dies maulidiya MA Darut Taqwa ikut serta mengundang penyanyi serta motivator Nuvi Wardhana. Kelima pada HUT Kemerdekaan RI Pondok Pesantren Ngalah ikut serta mengadakan upacara bendera yang bertempat dilapangan kampus Yudharta. Keenam tanggal 22-23 Juni 2019 kegiatan Camp Remaja Lintas Iman yang bertempat di Aula pancasila.

\section{DAFTAR PUSTAKA}

Ainiyah, Nur. (2013). Pembentukan Karakter Melalui Pendidikan Agama Islam. Al-Ulum, 13(1), Hal. 25.

Alam , Masnur. (2017). Studi Implementasi Pendidikan Islam Moderat dalam Mencegah Ancaman Radikalisme di Kota Sungai Penuh Jambi.jurnal Islamika. Volume 17, Nomor 2 tahun 2017.

Alam, Masnur. (2017). Studi Implementasi Pendidikan Islam Moderat dalam

Mencegah Ancaman Radikalisme di Kota Sungai Penuh Jambi. Jurnal Islamika, volume 17, nomor 2201.

Ariestoteles di kutip Thomas Lickona. 1991. Mendidik untuk membentuk karaker. Cortland, New York..

Arif, Mohammad. 2012. Pesantren Salaf Basic Pendidikan Karakter dalam Kajian Historis dan Prospektif. Kediri: STAIN Kediri Press

Azamiyah. 2017. Konsep Pendidikan Karakter Dalam Al-Qur'an Surah Alhujurat; 11-13. Tadarus: Jurnal Pendidikan Islam/Vol. 6, No. 1

Bagdan, Robert , Steven J. Taylor. 1993. Kualitatif Dasar-dasar Penelitian, (Surabaya: Terjemahan A. Khozin Afandi, Usaha Nasional,)

Baisuki, Asror. (2017). Penanaman Karakter Moderat Di Ma'had Aly Situbondo. Edukasi: Jurnal Penelitian Pendidikan Agama dan Keagamaan, 15.

Brosur Pondok Pesantren Ngalah Tahun 2019. Diambil pada tanggal 20 Juni 2019.

Dalmeri. (2014). Pendidikan Untuk Pengembangan Karakter (Telaah terhadap Gagasan Thomas Lickona dalam Educating For Character). Al-Ulum, 14(1). 
318 ][ Pembentukan Karakter Idiologi Moderat di Pesantren Ngalah Purwosari Pasuruan

Data santri putri periode bulan Robiul awal-Ramadhan tahun Tahun 14391440 Hijriyah . Diakses pada tanggal 20 Mei 2019

Dawuh romo kyai pengajian tafsir. Masjid Asrama A. 24 Desember 2018 jam 16.30 WIB

Kosim, Muhammad dalam buku Pendidikan Agama Islam dalam Prespektif Multikulturalisme. 2009. Sistem Pembelajaran Pendidikan agama Islam Berwawasan Multikultural. Jakarta: Balai Lintang Agama Jakarta.

Kosim, Muhammad. 2011. Urgensi Pendidikan Karakter. Karsa. Vol. IXI. No. 1 April 2011

M., Samani, \& Hariyanto. (2011). Konsep dan Model Pendidikan Karakter. Bandung. Remaja Rosda Karya

Misrawi, Zuhairi. 2010. Muslim Moderat Toleransi, Terorisme, dan Oase Perdamaian. Jakarta: Kompas Media Nusantara

Nasution, Harun. 1995. Islam Rasional Gagasan dan Pemikiran Prof. Dr. Harun Nasution. Bandung: Penerbit Mizan

Nur, Afrizal dan Muklis. (2016). Konsep Wasathiyah Dalam Al-Quran;(Studi

Komparatif Antara Tafsir Al-Tahrîr Wa At-Tanwîr Dan Aisar AtTafâsîr). Jurnal An-Nur, 4(2).

Nurjannah. 2013. Radikal vs Moderat Atas Nama Dakwa Amar Makruf Nahi Munkar dan jihad. Yogyakarta:Aswaja Pressindo

P, kamil Gurniwan. 2015. Pembentukan Krakter melalui Pendidikan Sosiologi. TINGKAP Vol. XI No. 1 Th.

Pernama, Setia, Irfan . (2019). Implementasi Toleransi Beragama di Pondok

Pesantren (Studi Kasus di Pondok Pesantren Universal Bandung). Hanifiya: Jurnal Studi Agama-Agama, 2(1)

Priatmoko, Sigit (2018, April). Pengarusutamaan Nilai-Nilai Islam Moderat Melalui Revitalisasi Pancasila dalam Pendidikan Islam. In Proceedings of Annual Conference for Muslim Scholars (No. Series 2,

Pustaka Amani Jakarta (Al-Quran terjemah departemen agam RI). 2005. AlQuran dan Terjemahnya. Jakarta: Pustaka Amani

R , I , Nur,. (2018). Implementasi Pendidikan Karakter di SD Muhammadiyah 2 Tulangan Sidoarjo. Universitas Muhammadiyah Sidoarjo

Rosidatun. 2018. Model implementasi pendidikan karakter. Gresik: Caremedia Comunication. 
S, Andria, Nofita., (2017). Implementasi Nilai At-Tawasuth (Moderat) Ahlussunnah Wal Jama'ah Dalam Pendidikan Karakter Di Ma Aswaja Ngunut Tulungagung. Skripsi Fakultas Tarbiyah dan Ilmu Keguruan, Jurusan Pendidikan Agama Islam IAIN Tulungagung.

Sahlan , Asmaun. (2013). Pendidikan Karakter dalam Perspektif Islam (Kajian Penerapan Pendidikan Karakter di Lembaga Pendidikan Islam). El-HiKMAH, 9(2),

Santri mbah KH. Munawir Kertosono dan santri Mbah KH. Sholeh Bahrudin. Sabilus salikin jalan para salik ensiklopedia thariqah/tasawwuf. 2012. Sengonagung: Pondok Pesantren Ngalah.

Santri Pondok Pesantren Ngalah. 2013. Ensiklopedi Fiqih Jawabul Masail Bermadzhab Empat. Sengonagung:Pondok Pesantren Ngalah.

Setiawan, Ayu Nanda. (2017). Pendidikan Karakter Sebagai Pilar Pembentukan Karakter Bangsa. Jurnal Semnastafis,

Setiawan, Deny. 2013. Peran Pendidikan Karakter dalam Mengembangkan Kecerdasan Moral. Jurnal Pendidikan Karakter, Tahun III, Nomor 1, Februari 2013.

Shaleh, Muwafik Akh., 2012, Membangun Karakter dengan Hati Nurani: pendidikan Karakter untuk Generasi Bangsa (Jakarta: Erlangga)

Suharto, Toto. Indonesianisasi Islam: Penguatan Islam Moderat Dalam Lembaga Pendidikan Islam Di Indonesia. Al-Tahrir, Vol. 17, No. 1 Mei 2017.

Undang-Undang No. 20 Tahun 2003, Tentang Sistem Pendidikan Nasional wahyudi , Chafid. 2013. Nahdhatul Ulama \& Civil Religion. Surabaya: Graha Ilmu.

Wening, Sri. (2012). Pembentukan karakter bangsa melalui pendidikan nilai. Jurnal Pendidikan Karakter, (1).

Yaqin, Ainul Muhammad. (2015). Strategi Pembentukan Sikap Moderat Santri: Studi Di Pondok Pesantren Ngalah Purwosari Pasuruan (Doctoral dissertation, UIN Sunan Ampel Surabaya). 
320 ][ Pembentukan Karakter Idiologi Moderat di Pesantren Ngalah Purwosari Pasuruan

Nurnal al-Murabli, Volume 4 Namar 2, Jumi 2019 